\title{
MORPHOLOGICAL VARIABILITY OF HELLEBORINES. I. DIAGNOSTIC SIGNIFICANCE OF MORPHOLOGICAL FEATURES IN EPIPACTIS HELLEBORINE (L.) CRANTZ, EPIPACTIS ATRORUBENS (HOFFM.) BESSER AND THEIR HYBRID, EPIPACTIS $\times$ SCHMALHAUSENII RICHT. (ORCHIDACEAE, NEOTTIEAE)
}

\author{
ANNA JAKUBSKA-BUSSE ${ }^{1}$, EDYTA M. GOLA ${ }^{2}$ \\ ${ }^{1}$ Department of Biodiversity \& Plant Cover Protection, \\ Institute of Plant Biology, University of Wrocław \\ Kanonia 6/8, 50-328 Wrocław, Poland \\ e-mail: Ajak@biol.uni.wroc.pl \\ ${ }^{2}$ Department of Plant Morphology and Development, \\ Institute of Plant Biology, University of Wrocław \\ Kanonia 6/8, 50-328 Wrocław, Poland
}

(Received: November 30, 2009. Accepted: April 16, 2010)

\begin{abstract}
The comparative analysis of leaf morphology was performed in E. helleborine (L.) Crantz, E.atrorubens (Hof$\mathrm{fm}$.) Besser, and their interspecific hybrid, Epipactis $\times$ schmalhausenii Richt. The aim of this research was to find out features that would be useful in the taxonomy of the genus Epipactis, and particulary their taxa of hybrid origin. In course of the studies special attention was paid to leaf morphology, mostly to their margins, presence of papillae, their shape and size, and to leaf structure. The thickness of the leaf blades manifested by number of spongy mesophyll cell layers, size of vascular bundles and the level of leaf sclerification were compared in the hybrid and both parental species. In E. helleborine and E. atrorubens the analyzed features were highly variable, especially in the former species, which is characterized by wide phenotypic plasticity. Morphological and anatomical features in E. Xschmalhausenii showed a transitional character to the parental species. Our results suggest that a single feature can not be of taxonomic value, but the combination of different traits has to be considered when distinguishing parental and hybrid taxa.
\end{abstract}

KEY WORDS: Epipactis helleborine, Epipactis atrorubens, Epipactis $\times$ schmalhausenii, leaf morphology, leaf margin, papillae, hybridization.

\section{INTRODUCTION}

Natural hybridization is a widespread phenomenon in plant kingdom. Some families, e.g. Poaceae or Orchidaceae, are more inclined to form hybrids than others (Potǔček and Čačko 1996; Ainouche et al. 2009; Steiner and Boni 2009). Particulary, the latter family, which is an evolutionary young group of plants, easily creates hybrids at the species and genus levels (Goodfery 1927; Dressler 1993). The lack of effective barriers preventing pollination may result, e.g., from spatial coexistence of many species, overlapping flowering seasons, and the presence of pollinators common to different species and in turn may enable crossing between the taxa (Darwin 1862; Dressler 1981; Peakall 2007). The absence of isolating mechanisms may be a consequence of a recent phylogenetic divergence of orchids and may indirectly be an evidence of their tendency to expand (Dressler 1993).

Hybrid forms are often difficult to identify because their morphological features are combination of parental species, which frequently show extreme phenotypic variability (Niinemets et al. 2003). In addition, hybrids may present clonal variations (Stebbins 1957). It means that local populations may be characterized by different morphological and genetic combination of taxonomically significant features that could make it impossible to undoubtedly identify a specimen.

Epipactis $\times$ schmalhausenii Richt. is one of the orchid hybrids reported in Poland (Bernacki 1989), which seems to be often indistinguishable from the parental species, i.e. E. helleborine (L.) Crantz and E. atrorubens (Hoffm.) Besser. Probably for this reason the hybrid taxon has only ra- 
rely been recorded in botanical literature after 1945 (Bernacki 1989; Adamowski 1995; Kwiatkowski 1997). According to Delforge (2005) one of the parental species, Epipactis helleborine (Broad-Leaved Helleborine), is the most common of the genus in Europe, occurring from Mediterranean to boreal zones, up to $2000 \mathrm{~m}$ a.s.l. It has also been recorded in North America. The species grows in shady places in both coniferous and mixed woodlands, sand-dune slacks, thickets, as well as it can spontaneously appear in town parks and gardens (Delforge 2005). It flowers from June to September depending on latitude and altitude (Williams et al. 1978; Delforge 2005) and demonstrates a wide range of phenotypic plasticity, which hinders the taxonomic diagnosis (Jakubska-Busse 2008). The second parental species, Epipactis atrorubens (Dark Red Helleborine), is significantly rarer in Poland than E.helleborine, mainly because of the devastation and resulting disappearance of its natural habitats. This species is widespread up to 2400 $\mathrm{m}$ a.s.l. in Europe, including British Isles, eastwards to Russia, Crimea, Caucasus and Iran. It is rare in Mediterranean area. E. atrorubens grows in rocky limestones, woodland margins, among bushes and grass in sand-dune slacks as well as dunes, and open woodlands (Delforge 2005). It flowers from May to August depending on latitude and altitude (Williams et al. 1978). E. ×schmalhausenii, a hybrid between both species mentioned above, is confined only to the localities of its parental species. $E$. $\times$ schmalhausenii has been found in many European countries (Hunt et al. 1975; Potůček and Čačko 1996). In Poland, it has been listed e.g. in flora of the Tatra National Park (Bernacki 1988), the Białowieża Primeval Forest (Adamowski 1995) and the Kaczawskie Mts. (Kwiatkowski 1997; Jakubska 2006). Despite E. ×schmalhausenii is recognized in Polish flora, description of the morphologi- cal features that may be of the taxonomic value is insufficient and frequently subjective, and, surprisingly, up to date there is a lack of the photographic documentation of the hybrid. Therefore, the aim of this research was to document morphological characteristics of parental species and the hybrid, indicate possible differences between them as well as point out "good" features, mostly in leaf morphology, which may be of the diagnostic value in distinguished taxon. Since Delforge (2005) showed "irregular serration" of the leaf margins "formed by hyaline teeth" in some Epipactis species and stated that it has a taxonomic significance, this feature was also analyzed in our research.

\section{MATERIALS AND METHODS}

Observations were conducted in field from the early vegetative phase (emergence of above-ground shoots) to the end of the generative phase (flowering) from May to August 2007-09.

Following populations of studied orchids were analyzed (Fig. 1): E. helleborine - Zakrzów-Kotowice near Wrocław (ATPOL CE 50); Nowe Rochowice in the Kaczawskie Mts. (ATPOL BE 62) and Mysłów-Sobocin near Bolków (ATPOL BE 61); E. atrorubens - Nowe Rochowice (ATPOL BE 62) and Mysłów-Sobocin near Bolków (ATPOL BE 61); E. ×schmalhausenii - Nowe Rochowice (ATPOL BE 62). All ATPOL locations are given according to Zając (1978).

The choice of populations examined was justified by the frequency of the ramets. E. helleborine population in $\mathrm{Za}$ krzów-Kotowice is estimated for four to six thousand shoots (Jakubska and Orłowski 2003), whereas in Nowe Rochowice each co-existing population of E. atrorubens and

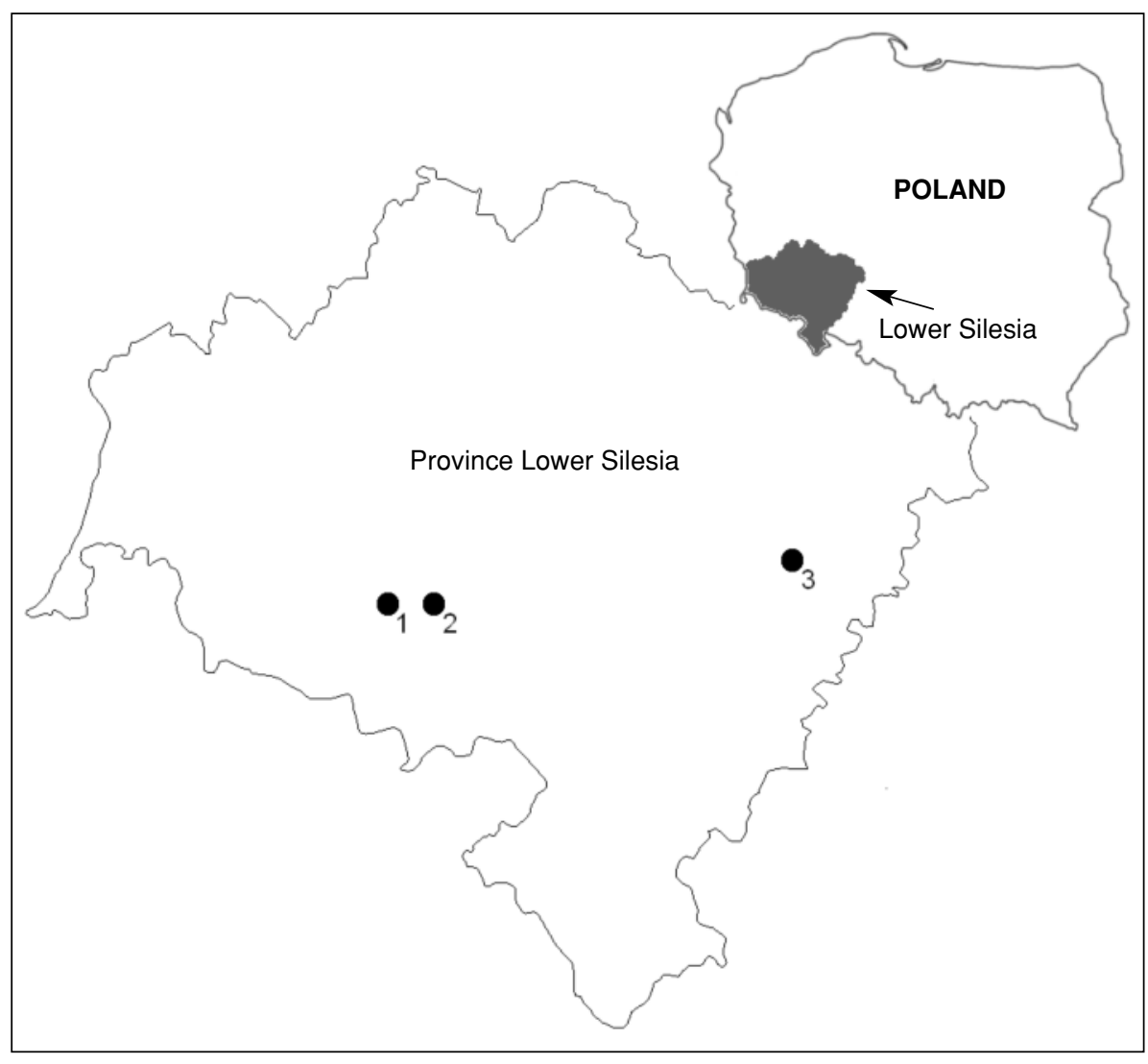

Fig. 1. Distribution of populations studied shown at the ATPOL map (Zając 1978). Localities: 1 - Mysłów-Sobocin; 2 - Nowe Rochowice; 3 -Zakrzów-Kotowice. 
E. helleborine counts about 200 ramets. Population of $E$. $\times$ schmalhausenii in Nowe Rochowice was selected based on co-occurrence and frequency of parental species.

Individual plants of E. helleborine, E. atrorubens and their hybrid $E$. $\times$ schmalhausenii were documented in natural populations by photographs. The third leaves of studied taxa, counted from the stem bases, were collected for anatomical and morphological analyses. Sampled leaf fragments were fixed in field in the formalin-acetic acid-alcohol mixture (FAA, with 50\% ethanol; Ruzin 1999) and then processed according to different protocols. Additionally, some comparative analyses were conducted on herbarium materials.

To analyze the overall leaf morphology, the fixed material was hydrated in a gradual ethanol series and then thoroughly rinsed with distilled water. Leaves were subsequently cleared with $10 \% \mathrm{KOH}$ (Ruzin 1999) in the $60^{\circ} \mathrm{C}$ to remove cell contents and visualize cellular patterns. Similarly, leaves coming from different vouchers were hydrated in warm water, and then cleared in $10 \% \mathrm{KOH}$ in room temperature.

The anatomical structure of leaves was studied on the transverse sections. For such an analysis, the previously fixed material was dehydrated in an increasing tertiary-butyl alcohol series followed by embedding in Paraplast X-tra (Fluka, BioChemika; Ruzin 1999). Series of transverse sections, 5-7 $\mu \mathrm{m}$ thick, were cut on a rotary microtome (Leica RM2135; Leica Instruments) and counterstained with the alcian blue-safranin mixture (Sigma; O'Brien and McCully 1981).

Leaf morphology was documented in a stereo microscope Olympus SZX9 and an Olympus BX-50 microscope with a DP71 camera and imaging software Cell B (Olympus Optical Co.).

Fixed material was deposited in the Institute of Plant Biology, University of Wrocław.

\section{RESULTS}

In studied taxa the flower morphology is well recognized (Fig. 2 A-C inlets; e.g. Bernacki 1988, 1989; Szlachetko and Rutkowski 2000; Pridgeon et al. 2005) thus the labellum features were not taken under consideration in this research and the main focus was on the leaf morphology.

\section{Leaf shape and coloration}

Leaves of E. helleborine were ovate to broadly ovate, decreasing in size upwards; fresh-green; margins green (Fig. 2A, D, G); sheathing pale green to whitish (Fig. 2D), rarely with a pale violet tint (Fig. $2 \mathrm{G}$ ). The leaves of $E$. atrorubens are usually narrower than in the previous species, lanceolate; green; margins, leaf tips, and main veins as well as leaf bases and sheaths with intensive purple or reddish coloration (Fig. 2C, F). Leaves of E. Xschmalhausenii were ovate to ovate-lanceolate at the stem base, elongated to lanceolate in the upper part of the stem; green to cyan-greenish; margins, main veins and basal part of sheaths with pale violet or pinkish-purple tint (Fig. 2B, E). Generally, they are similar in shape to leaves of E. helleborine. Due to the presence of pigmentation and its location they resemble E. atrorubens but hybrid leaves are rather pink in shade. Although E. helleborine have sometimes a pale violet tint
(Fig. 2G) of basal leaf sheaths, but coloration in $E$. $\times$ schmalhausenii is much more intensive (Fig. 2B) and is conspicuous along the stem similarly to E. atrorubens.

\section{Leaf margins}

Leaves in all taxa studied have macroscopically entire margins (Fig. 2D-G), sometimes with slight undulation (Fig. 2A, D). However, microscopic examination reveals the presence of specific margin cells which have protruding outer cell walls and form papillae (Figs 3, 4A-F). Papillae are arranged in two or three rows at the leaf margin with the middle one being the most pronounced (Fig. 3). The number and density of papillae is variable in a particular leaf, one specimen and between different ramets. Differences between examined taxa are subtle: in E. helleborine papillae are usually elongated and conical, slightly inclined, specifically in the middle row, whereas in lateral rows they are shorter and more rounded (Figs 3, 4A, D). In E. atrorubens almost all margin cells form papillae. They are shorter than in the previous species, more dome-like than conical (Fig. 4C, F). In E. ×schmalhausenii papillae in the central row are of variable length, similar in shape to those of $E$. helleborine, while in lateral rows they are shorter and dome-like as in E. atrorubens (Fig. 4B, E).

Similar papillae occur along veins at the abaxial and adaxial side of the leaf blades (Fig. 3). They are usually arranged in three rows; up to 5 rows can be present at the main veins. They are pronounced in mature leaves of all taxa studied but in expanding leaves papillae may be less discernible.

\section{Leaf blade structure}

The characteristic feature of leaf blades in all taxa studied was the presence of idioblasts containing crystals in the form of raphides (Fig. 4D-F). Raphid idioblasts are usually thin-walled, enlarged and arranged in rows of cells that are possibly of common origin.

The leaf structure of analyzed Epipactis taxa is similar in the cross-sections although differs in the number of mesophyll cell layers and thus in the thickness of the leaf blades, as well as in the amount of sclerenchymatous elements. $E$. helleborine leaf blade is relatively soft and thin, at the cross section consists of 4-5 layers of spongy mesophyll cells (Fig. 4G, J) apart from abaxial and adaxial epidermis, whereas in E. atrorubens (Fig. 4I, L) and E. Xschmalhausenii (Fig. 4H, K) leaf blades are more rigid and thick, and contain up to 8 or 6 mesophyll cell layers, respectively. The vascular bundles in examined taxa are surrounded by mesophyll sheaths. In E. helleborine, there are few sclerenchymatous fibers at the abaxial side of phloem in the bundle (Fig. 4G), mostly visible in the main veins. In E. atrorubens, vascular bundles are bigger in size comparing with the previous species with numerous well-developed thickwalled sclerenchmatous fibers adjacent to phloem at the abaxial side and some fibers enclosing the bundle at the adaxial side (Fig. 4I). In E. ×schmalhausenii, vascular bundles are similar to those in E. atrorubens in respect to the size and distribution of sclerenchymatous elements but the amount of fibers seems to be smaller in the hybrid (Fig. 4H). In E. atrorubens and E. Xschmalhausenii well-developed fibers are pronounced in almost all veins not only the main ones. 


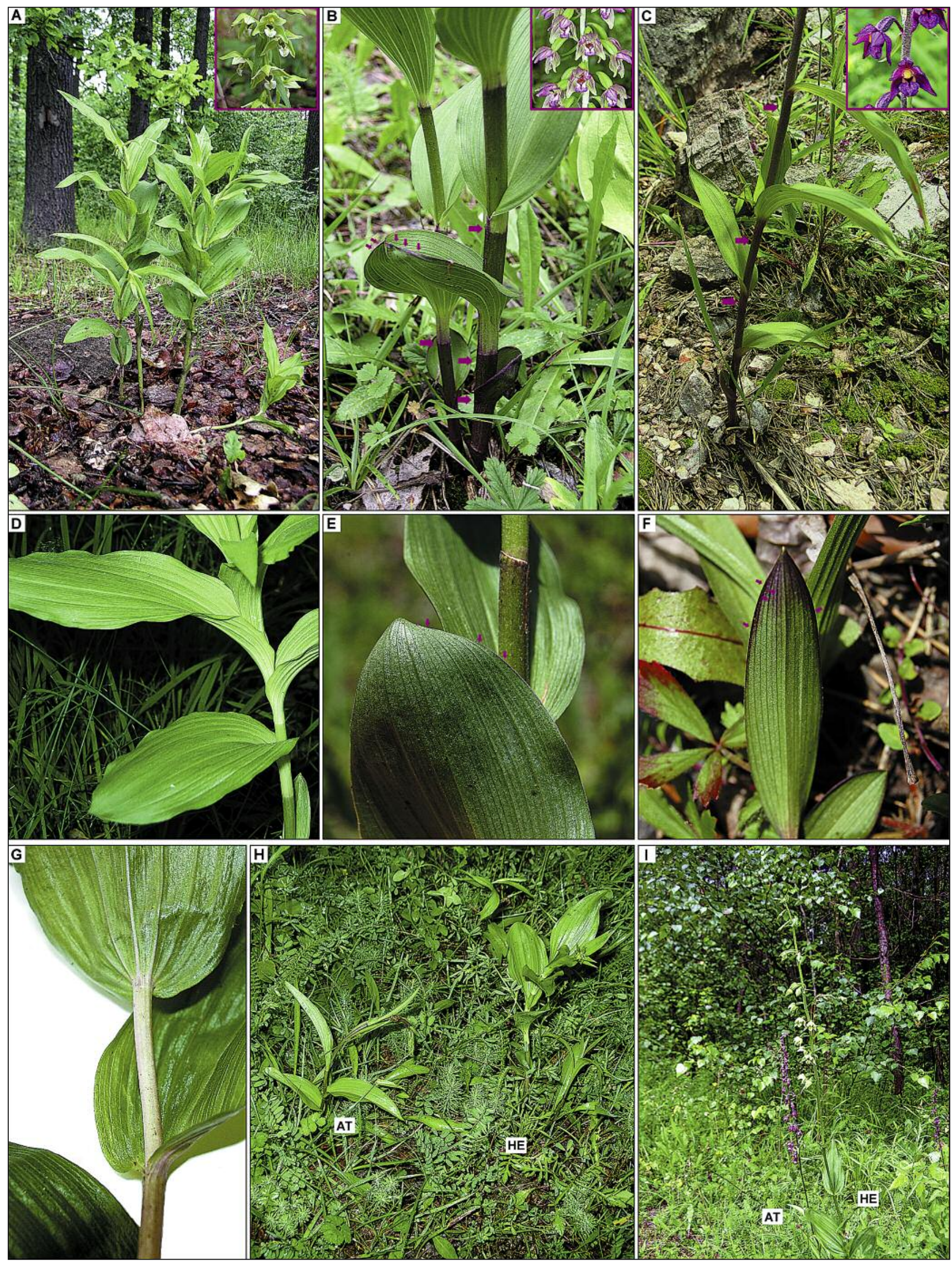

Fig. 2. Morphological features of the studied Epipactis taxa: E. helleborine (A, D, G), E. xschmalhausenii (B, E) and E. atrorubens (C, F). The habitus (A$-\mathrm{C}$ ), flowers (A-C, inlets), close-ups of leaves (D-G), and comparison of E. helleborine (HE) and E. atrorubens (AT) growing side-by side (H-I). Please, note the violet tint of the leaf margins, tips, veins and sheaths of $E$. xschmalhausenii (B, E; indicated by arrows) and more reddish or purple coloration in E. atrorubens (C, F; indicated by arrows). E. helleborine has typically fresh-green leaves and pale sheathing (A, D), although slight pale violet tint may be present at the lower leaf sheathing $(\mathrm{G})$. 

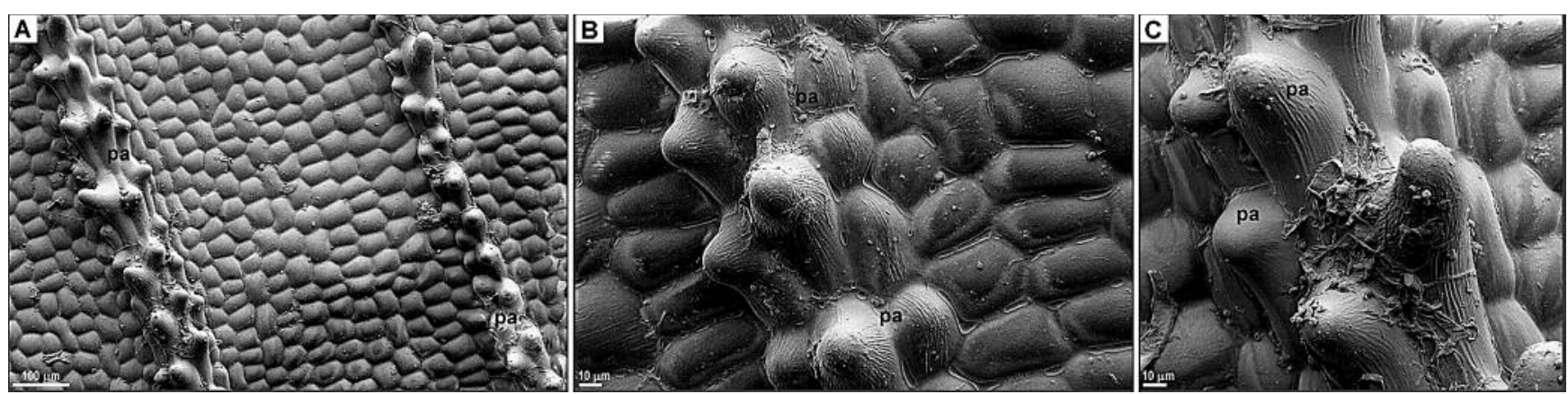

Fig. 3A-C. SEM images of the E. helleborine adaxial leaf surface presenting rows of papillae (pa) above veins.
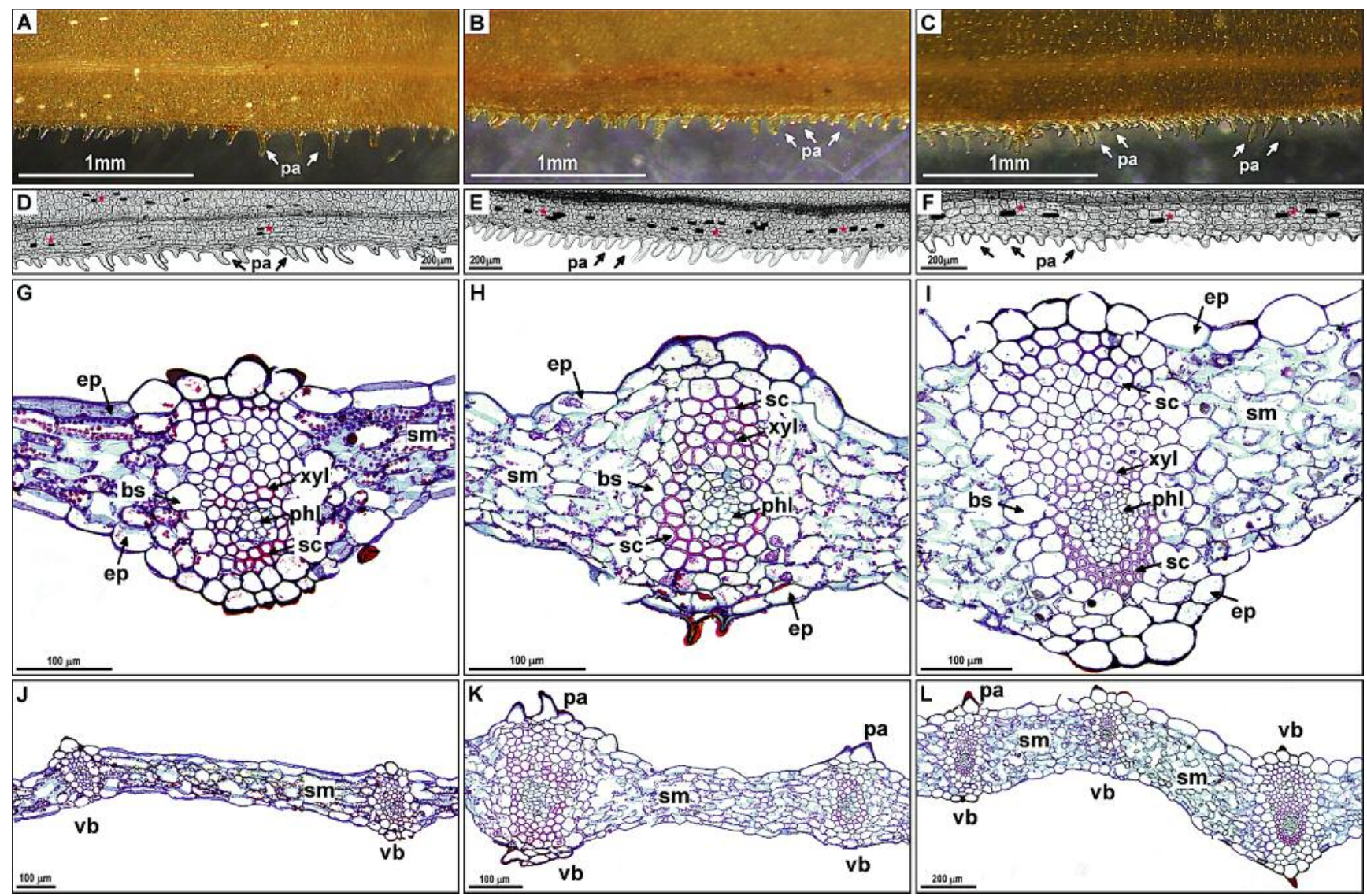

Fig. 4. Leaf micromorphology and anatomy in taxa studied: E. helleborine (A, D, G, J), E. ×schmalhausenii (B, E, H, K) and E. atrorubens (C, F, I, L). A-C a stereomicroscope view of the leaf margins showing presence of characteristic papillae (pa; pointed out with arrows). D-F - leaf margins viewed in a microscope show magnified cone-like margin cells (papillae; pa; pointed out with arrows). Characteristic raphid idioblasts are marked with red stars. G-L leaf cross-section presenting general anatomy of leaves (G-L) and magnified vascular bundles (G-I). All leaves at the images presented are oriented with the adaxial side upwards. Please note the different numbers of spongy mesophyll layers forming leaf blades in studied taxa. Abbreviations: bs - bundle sheath; ep - epidermis; pa - papillae; phl - phloem; sc - sclerenchyma; sm - spongy mesophyll; vb - vascular bundle; xyl - xylem.

\section{DISCUSSION}

No other family but orchids has such a particular tendency to create hybrids which is possibly related to the lack of hybridization barriers within and between the genera (Dressler 1981; Moccia et al. 2007; Peakall 2007). This phenomenon may result from the recent divergence of orchids (Dressler 1981; Dahlgren et al. 1985; Judd et al. 2002) which due to the short evolution time may not specify genetic barriers between taxa. However, the reasons of insufficient genetic isolation have not been clearly explained so far.

Hybrids may come into being where related species or genera grow close together and bloom at the same time. In Orchidaceae natural hybrids are often not distinguishable from their parental species what can explain the paucity of the literature data referring to hybrid morphology and origin. An important and drastically underestimated feature in Epipactis taxonomy is an extremely wide phenotypic plasticity exemplified by $E$. helleborine (Jakubska-Busse 2008). It has to be taken under consideration, when the artificial key is constructed to distinguish different taxa, since this plasticity applies also to the resultant interspecific hybrid combinations, as shown for E. Xschmalhausenii by Bernacki (1988), Adamowski (1995), and Potůček and Čačko (1996). Thus, thorough morphological analyses are necessary to establish the range of variability and find possible and recurrent combinations of hybrid features. In turn, it will improve taxonomical descriptions and allow us to precisely define feature combination essential for diagnosis. In addition, although E. helleborine, E. atrorubens 
and their hybrid can usually be easily recognized in field, the herbarium material may be doubtful because of changes in the preserved tissues or often incomplete material (please, compare Adamowski 1995).

Data presented in this paper show, what is congruent with the literature (e.g. Potůček and Čačko 1996; Moccia et al. 2007), that hybrids usually demonstrate features transitional to those of parental species, although some characters of one parent may prevail (Peakall 2007). For example, domination of $E$. helleborine phenotypic features was observed in Poland by Bernacki (1988) and Adamowski (1995). In E. ×schmalhausenii population, analyzed in this paper, E. helleborine phenotype was manifested by the plant size, the leaf and flower shape, form of leaf margins and papillae. On the other hand, anatomical features such as the thickness of the leaf blades (number of mesophyll cell layers), size of vascular bundles and amount of the sclerenchymatous fibers as well as coloration of leaf tips, sheaths and veins were possibly inherited after the other parental species, namely E. atrorubens. They may suggest hybrid adaptation to the more xerothermic habitat than typical of E. helleborine and may facilitate inbred expansion also in antropogenically changed environments, what was also observed in the Białowieża Primeval Forest (Adamowski 1995).

In the current research, the special attention was paid to the structure of leaf margins as the presence of "hyaline teeth" was suggested to be of diagnostic value in identification of some Epipactis taxa (Delforge 2005). Microscopic analysis revealed that these outgrowths are in fact the epidermal margin cells which have conical or dome-like shape and thus they may be classified as papillae (Wilkinson 1979). No hyaline teeth, hairs or cells were detected at the leaf margins in the course of the studies. The size and shape of papillae showed considerable intraspecific variability therefore this feature does not allow us to faultlessly distinguish between taxa.

Theoretically, two combinations that result in a hybrid, E. $\times$ schmalhausenii, are equally probable, i.e. pollination of E. helleborine with the pollen of E. atrorubens or opposite situation, namely pollination of E. atrorubens with the pollen of E. helleborine, yet life expectancy, condition as well as morphological feature combination in both types of hybrids may not be the same. Additionally, E. ×schmalhausenii may interbreed with parental species (Bernacki, 1988, Potůček and Čačko 1996) increasing the range of phenotypic variability and making it even more difficult to unequivocally identify the hybrid. It seems that only holistic approach including among others morphological, molecular, and ecological data coupled with statistic analysis of taxonomically significant features may help us to construct clear and accurate artificial key to dubious taxa, including hybrids.

\section{ACKNOWLEDGEMENTS}

The authors would like to thank Drs Ewa Szczęśniak and Krzysztof Świerkosz for making herbarium materials available for the examination and Michał Śliwiński MSc. for assistance in the field.

\section{LITERATURE CITED}

ADAMOWSKI W. 1995. Phenotypic variation of Epipactis helleborine $\times E$. atrorubens hybrids in anthropogenic conditions. Acta Soc. Bot. Pol. 64: 303-312.

AINOUCHE M.L., FORTUNE P.M., SALMON A., PARISOD C., GRANDBASTIEN M.-A., FUKUNAGA K., RICOU M., MISSET M.-T. 2009. Hybridization, polyploidy and invasion: lessons from Spartina (Poaceae). Biol. Invasions 11: 1159$-1173$.

BERNACKI L. 1988. Kruszczyk Schmalhausena Epipactis ×schmalhausenii Richt. - nowy gatunek polskiej części Tatr Zachodnich. Chrońmy Przyr. Ojczystą 44.1: 80-87. (in Polish)

BERNACKI L. 1989. Lista mieszańców storczykowatych (Orchidaceae) we florze Polski. Acta Biol. Siles. 11: 48-65.

DAHLGREN R.M.T., CLIFFORD H.T., YEO P.F. 1985. The Families of the Monocotyledons. Structure, Evolution, and Taxonomy. Springer-Verlag, Berlin, $520 \mathrm{pp}$.

DARWIN C. 1862. On the various contrivances by which British and foreign orchids are fertilised by insects, and on the good effects of intercrossing. John Murray London, $365 \mathrm{pp}$.

DELFORGE P. 2005. Orchids of Europe, North Africa and the Middle East. A \& C Black, London, 640 pp.

DRESSLER R.L. 1981. The Orchids: Natural History and Classification. Cambridge, Massachusetts: Harvard University Press.

DRESSLER R.L. 1993. Phylogeny and classification of the orchid family. Dioscorides Press, Portland, $314 \mathrm{pp.}$

GODFERY C.M.J. 1927. Natural orchid hybrids. Genetica 9(1-2): 19-38.

HUNT P.F., ROBERTS R.H., YOUNG D.P. 1975. Orchidaceae. In: Hybridization and Flora of the British Isles. Stace C.A. (ed.). Academic Press London, New York, San Francisco, pp. 473-507.

JAKUBSKA A., ORŁOWSKI G. 2003. Naturalnie występujące gatunki storczyków na terenie Wrocławia i okolic. In: Korczyński M. (ed.), "Flora Miast", Kujawsko-Pomorskie Centrum Edukacji Ekologicznej, Bydgoszcz, pp. 87-91. (in Polish)

JAKUBSKA A. 2006. A new locality of Epipactis ×schmalhausenii Richt. in the Kaczawskie Mountains (the Western Sudety Mts., SW Poland). Čas. Slez. Muz. Opava (A): 55: 241-243.

JAKUBSKA-BUSSE A. 2008. The range and significance of phenotypic plasticity of Broad-leaved Helleborine Epipactis helleborine (L.) CRANTZ for taxonomy (Orchidaceae: Neottieae). In: L. Borowiec, D. Tarnawski (eds), The importance of natural history museum of taxonomy. Polish Taxonomical Monographs, Wrocław, 15: 85-92.

JUDD W.S., CAMPBELL C.S., KELLOGG E.A., STEVENS P.F., DONOGHUE M.J. 2002. Plant Systematics: A Phylogenetic Approach. 2nd ed. Sinauer Associates, Sunderland, 576 pp.

KWIATKOWSKI P. 1997. Interesujące i rzadkie gatunki roślin naczyniowych Gór Kaczawskich i Pogórza Kaczawskiego II. Acta Universitatis Wratislaviensis No 1936, Prace Botaniczne LXXIII, Wrocław, pp. 47-62. (in Polish)

MOCCIA M., WIDMER A., COZZOLINO S. 2005. The strength of reproductive isolation in hybridizing food deceptive orchids. Mol. Ecol. 16: 2855-2866.

NIINEMETS Ü., VALLADARES F., CEULEMANS R. 2003. Leaf-level phenotypic variability and plasticity of invasive Rhododendron ponticum and non-invasive Ilex aquifolium cooccurring at two contrasting European sites. Plant Cell Environ. 26: 941-956.

O'BRIEN T.P., McCULLY M.E. 1981. The study of plant structure: principles and selected methods. Melbourne, Australia: Termarcarphi Pty Ltd.

PEAKALL R. 2007. Specioation in the Orchidaceae: confronting the challenges. Mol. Ecol. 16: 2834-2837.

POTU゚ČEK O., ČAČKO L. 1996. Všechno o orchidejích. Nakladatelstvi Slovart, Praha, pp. 85. (in Czech) 
PRIDGEON A.M., CRIBB P.J., CHASE M.W., RASMUSSEN F.N. 2005. Genera Orchidacearum, vol 4, Epidendroideae (part 1). Oxford University Press, Oxford, pp. 487-515.

RUZIN S.E. 1999. Plant microtechnique and microscopy. New York, Oxford University Press.

STEBBINS G.L. 1957. Self fertilization and population variability in the higher plants. Am. Nat. 91: 1-337.

STEINER K.E., BONI B.C. 2009. Hybridization between two oil-secreting orchids in South Africa. Plant Syst. Evol. 277: 233-243.

SZLACHETKO D.L., RUTKOWSKI P. 2000. Gynostemia Orchidalium I. Acta Bot. Fennica 169: 1-380.
WILKINSON H.P. 1979. The plant surface (mainly leaf). In: Metcalfe C.R., Chalk L. (eds), Anatomy of dicotyledons. Vol. I. Systematic anatomy of the leaf and stem, with a brief history of the subject. 2nd ed., Oxford University Press, Oxford, pp. 97-165.

WILLIAMS J.G., WILLIAMS A.E., ARLOTT N. 1978. A Field Guide to the Orchids of Britain and Europe with North Africa and the Middle East. Collins, London, pp. 1-176.

ZAJĄC A. 1978. Założenia metodyczne "Atlasu rozmieszczenia roślin naczyniowych w Polsce”. Wiad. Bot. 22(3): 145-155. (in Polish) 